JERZY EISLER

Instytut Historii PAN, Warszawa

Instytut Pamięci Narodowej, Warszawa

\title{
POLSKA RZECZPOSPOLITA LUDOWA - SZKIC DO ROZWAŻAŃ O LAICYZACJI PAŃSTWA
}

Celem niniejszego eseju jest zastanowienie się nad tym, w jaki sposób i ewentualnie $\mathrm{w}$ jakim zakresie polityka kolejnych ekip politycznych w okresie Polski Ludowej przyczyniała się do laicyzacji i sekularyzacji państwa oraz ateizacji życia publicznego. Jednocześnie interesująca wydaje się kwestia, w jakim stopniu te zjawiska - świadomie lub nie współgrały z procesami ulegania zeświecczeniu społeczeństw na Zachodzie czy - szerzej - z sygnalizowanym nierzadko zjawiskiem dechrystianizacji Europy. Należy przy tym zwrócić uwagę na fakt, że niemal wszystkie te określenia (może z wyjątkiem dechrystianizacji) w najróżniejszych słownikach językowych publikowanych w latach PRL ${ }^{1}$ objaśniane są jedne za pomocą drugich, czyli traktuje się je jako synonimy. Nie umiem przy tym odpowiedzieć na ważne skądinąd pytanie, czy na taki sposób opisu tych haseł miało wpływ to, że powstały one w okresie PRL, czy też raczej przyjęcie takiej a nie innej metodologii opisu. Jednocześnie nie zapominam, że sama ogólna wymowa czy - tym bardziej sposób objaśniania tych haseł mogły być obciążone ideologicznie, wszak religia i Kościół katolicki w owych czasach postrzegane były jako zjawiska/instytucje wrogie. Niemniej jednak - przy wszystkich niezbędnych zastrzeżeniach i ograniczeniach - także i ja będę określenia te traktował

${ }^{1}$ Tytułem przykładu zob.: Encyklopedia katolicka, t. 1-20, red. F. Gryglewicz i in., Lublin 1973-2014; W. Kopaliński, Słownik wyrazów obcych i zwrotów obcojęzycznych, (wyd. 11), Warszawa 1998; Religia. Encyklopedia PWN, t. 1-10, red. nauk. T. Gadacz, B. Milerski, Warszawa 2001-2003; Słownik języka polskiego, red. M. Szymczak, t. 1-3, Warszawa 1978-1981; Słownik języka polskiego, red. W. Doroszewski, t. 1-11, Warszawa 19641969 (1996-1997). 
synonimicznie ${ }^{2}$. Zanim jednak przejdę do właściwych rozważań, pozwolę sobie na pewną dygresję o charakterze osobistym.

W latach 1994-1997 byłem dyrektorem Szkoły Podstawowej i Liceum Ogólnokształcącego im. Adama Mickiewicza przy Ambasadzie Rzeczypospolitej Polskiej w Paryżu. Z tego powodu moje cztery córki uczęszczały nie tylko do tej szkoły, która funkcjonowała w praktyce dwa dni w tygo$\mathrm{dniu}^{3}$, ale również pobierały naukę $\mathrm{w}$ - odpowiednich dla swojego pozio$\mathrm{mu}$ - szkołach francuskich. Jako ojciec za każdym razem na początku roku szkolnego musiałem w uczniowskich dzienniczkach podpisywać się pod wydrukowanym zdaniem następującej treści: „Szkoła laicka i świecka jest fundamentem Republiki”. Mój podpis miał świadczyć o tym, że przyjmuję do wiadomości tę fundamentalną dla obowiązującego we Francji systemu zasadę. Jednocześnie obowiązek składania podpisu pod tego typu - było nie było - deklaracją ideową czy wręcz światopoglądową skłaniał mnie do pewnych powierzchownych, ale jednak przecież znamiennych porównań V Republiki do PRL.

Zresztą miałem wówczas, jak i mam obecnie przeświadczenie, że paradoksalnie są i zarazem nie są to porządki rzeczy, które mogą być ze sobą

${ }^{2} \mathrm{Na}$ ogół sekularyzacja - będąca synonimem laicyzacji - wywodzona z łacińskiego słowa saecularis (świecki) oznacza przejście majątków, urzędów lub terytoriów spod władzy kościelnej pod władzę świecką. Ponadto jest to prawne przeniesienie osoby zakonnej do kleru świeckiego lub osoby duchownej do stanu świeckiego. Natomiast laicyzacja w sensie politycznym polega na ograniczaniu przez państwo wpływów Kościoła i religii za pomocą aktów prawnych, ustanawiających rozdział Kościoła od państwa (konfiskata dóbr kościelnych, sekularyzacja szkolnictwa itp.). W sensie socjologicznym laicyzacja przejawia się słabnięciem więzi religijnych, a zwłaszcza spadkiem uczestnictwa w praktykach religijnych, odchodzeniem od norm etycznych i obyczajowych głoszonych przez Kościół i zmniejszaniem się autorytetu duchowieństwa. Z kolei w sensie psychologicznym laicyzacja manifestuje się przez zmiany w postawach światopoglądowych, to znaczy odchodzenie od wiary religijnej w kierunku agnostycyzmu, ateizmu lub indyferentyzmu.

Wydaje się, że nieco mocniejszą, a zarazem dla wielu ludzi bardziej negatywną wymowę ma - zaczerpnięte z języka greckiego określenie ateizm ( $a$ - „nie”, theós „Bóg”) , oznaczające w praktyce negowanie istnienia Boga. Rozróżnia się przy tym zwykle ateizm dogmatyczny, kategorycznie zaprzeczający istnieniu Boga, ateizm sceptyczny, zakładający niemożność udowodnienia jego istnienia, a przez to bliski agnostycyzmowi, oraz ateizm praktyczny, w ogóle negujący ważność samego problemu istnienia Boga. Ateizm jest też często utożsamiany z areligijnością, bezbożnością. Terminem ateizm określano na przykład niekiedy sprzeciw wobec religii państwowej i oficjalnego Kościoła, indyferentyzm religijny, relatywizm aksjologiczny, , ucieczkę od religii” w sferę prywatności itp. Za ,ateistyczne” lub „ateizujące” uważano też wszelkie przejawy desakralizacji życia oraz zaniku praktyk religijnych.

${ }^{3}$ W tamtych latach zajęcia w Szkole Polskiej w Paryżu odbywały się w czasie, gdy nieczynne były szkoły francuskie, to znaczy w środy od godziny 7.50 do 20.10 oraz w soboty od 12.00 do 20.10 . 
porównywane. Trudno bowiem porównywać państwo demokratyczne i liberalne z niesuwerennym, uzależnionym od sąsiedniego mocarstwa, rządzonym po dyktatorsku. Nie zapominam również, że fala gwałtownej laicyzacji we Francji przetoczyła się na przełomie XIX i XX w., osiągając apogeum wraz z wprowadzeniem w 1905 r. głośnej ustawy o rozdziale Kościoła od państwa. Wtedy to - przypomnijmy - premier Émile Combes posunął się aż do sekwestrowania mienia kościelnego. Zakazano wówczas nauczania wszystkim księżom należącym do zakonów i zamknięto około 1600 domów zakonnych ${ }^{4}$.

Z czasem „rewolucyjny zapał antyklerykałów” osłabł, do czego zapewne przyczyniły się m.in. traumatyczne doświadczenia Francji i Francuzów z lat I wojny światowej. Trudno także jednak zapomnieć, że polityczno-społeczny kontekst laicyzacji czy sekularyzacji życia publicznego był we Francji składnikiem modernizacji państwa. Tymczasem w Polsce fala urzędowego antyklerykalizmu pojawiła się pół wieku później, ale była za to bodaj jeszcze brutalniejsza. Co więcej, w wypadku Polski po II wojnie światowej laicyzacja i sekularyzacja były elementami zupełnie innego projektu. Chodziło tutaj o niemal całkowite przekształcenie otaczającego świata i stworzenie "nowego człowieka” - docelowo wolnego od "religijnych miazmatów”. Władze państwowe Francji -zwłaszcza od czasu I wojny światowej raczej nie odmawiały obywatelom prawa do praktyk religijnych, podczas gdy rządzący PRL chcieli je wyeliminować. Były to zatem zjawiska o pewnym podobieństwie form, ale całkowicie różnym kontekście politycznym i społecznym.

W wypadku powojennej Polski nie tyle zresztą chodziło o rozdział Kościoła od państwa, ile o marginalizację, a docelowo zapewne i likwidację tego pierwszego. Kościół katolicki uosabiał bowiem wiele wartości etycznych, moralnych, kulturowych, które były sprzeczne z wizją nowego „postępowego" człowieka; nie było zatem miejsca na pokojową koegzystencję. Nauka społeczna Kościoła stała w zupełnej sprzeczności z wizją nowej władzy. To były praktycznie dwa zupełnie różne światy, a w PRL miejsce było tylko na jeden $z$ nich - ten socjalistyczny. Powiedziałbym tak: w PRL cel, środki i metody były totalne, gdyż miały doprowadzić do totalnej zmiany. We Francji procesy laicyzacji i sekularyzacji - nawet w najbardziej gwałtownej fazie z przełomu XIX i XX w. - przebiegały w ramach państwa demokratycznego i liberalnego, co raczej musiało mitygować radykalnie nastawionych antyklerykałów.

${ }^{4}$ J. Makowski, Kościół Francji. Wśród kontrowersji i osiagnięć katolicyzmu francuskiego, Warszawa 1969, s. 18. 
Być może właśnie dlatego, że ów zapał walki o „laicką i świecką Republikę" nie był nieograniczony, Paryż pozostał tym miastem na świecie, w którym prawdopodobnie znajduje się najwięcej placów, bulwarów, alei, ulic, pasaży i zaułków mających w nazwie obok imienia patrona słowo „święty” względnie „święta”. Tytułem przykładu można przypomnieć najbardziej znane z nich: Saint Denis, St-Germain, St-Honoré, St-Michel, St-Placide i St-Suplice. Co ciekawe, we Francji nikomu nie przyszło do głowy, żeby owe „święte” przymiotniki usuwać z nazw ulic i placów, a jeżeli nawet przyszło, to nie był w stanie tego przeforsować. W PRL natomiast nie zawahano się, aby na przykład ulice Świętej Barbary, Świętego Bonifacego czy Świętego Wincentego w Warszawie stały się po prostu ulicami: Barbary, Bonifacego i Wincentego. Analogicznie postąpiono w wielu innych polskich miastach, czasem decydując się w ogóle na radykalną zmianę nazewnictwa. Na przykład jedna z głównych arterii Poznania przed wojną i po 1989 r. nosząca imię Święty Marcin (wyjątkowo - wbrew zasadom polskiej gramatyki - w mianowniku a nie w dopełniaczu) w czasach PRL miała za patrona Armię Czerwoną. Gdy porównuje się „święte ulice” w powojennej Polsce i we Francji, wypada zauważyć, że ekipy polityczne IV i V (,laickich i świeckich") Republik okazały się w tym względzie bez porównania bardziej powściągliwe i tolerancyjne niż władze PRL. Nie wolno jednak zapominać, że w tym wypadku zmiana nazw ulic - podobnie zresztą jak szereg innych inicjatyw władz - miała charakter systemowy; była elementem tworzenia państwa świeckiego i zarazem kształtowania nowego socjalistycznego człowieka.

Wrażenie to ulega jeszcze pogłębieniu, gdy przypomni się ,ingerencję" rządzących Polską Ludową w starożytne dzieje świata i walkę - w końcu skuteczną - o używanie w najszerzej rozumianym dyskursie publicznym (środki masowego przekazu, szkolna edukacja na wszystkich szczeblach, badania naukowe, publikacje książkowe itp.) wyłącznie datacji „przed naszą erą” (p.n.e.) względnie „naszej ery” (n.e.), zamiast obowiązującej powszechnie w Polsce przed II wojną światową formuły „przed narodzeniem Chrystusa" (prz. nar. Chr., ante Christum natum). Tymczasem we Francji (podobnie zresztą jak w Wielkiej Brytanii) nikomu coś takiego nie przyszło do głowy i cały czas używane jest tam w sferze publicznej wyrażenie „avant Jesus Christ” ewentualnie ,après Jesus Christ”.

Co najmniej równie niekorzystnie dla polskich komunistów wypada porównanie do Francji, gdy analizuje się kwestię przeznaczonych głównie, choć nie wyłącznie, dla osób starszych, chorych i niepełnosprawnych transmisji niedzielnych mszy świętych $w$ radio i telewizji. W latach siedemdziesiątych, gdy praktycznie nikt w Polsce jeszcze nawet nie marzył o takich przekazach radiowych, we Francji co niedziela nabożeństwa 
były transmitowane w telewizji. Do tego trzeba oczywiście dodać bogatą nad Sekwaną kolekcję regionalnej i centralnej prasy katolickiej. W PRL zaś - przypomnijmy - radiowe transmisje niedzielnych mszy, o które protestujący upominali się $\mathrm{w}$ jednym $\mathrm{z}$ dwudziestu jeden postulatów strajkowych w sierpniu 1980 r. w Stoczni im. Lenina w Gdańsku, zostały wprowadzone kilka tygodni później, po podpisaniu „umów społecznych" w Szczecinie, Gdańsku i Jastrzębiu.

Przez dekady trudno było nawet myśleć o transmisji nabożeństw, skoro w okresie stalinowskim przez kilka lat nie wolno było odtwarzać w Polskim Radiu kolęd.Gdy pojawiły się one ponownie przed Świętami Bożego Narodzenia w 1954 r.w - sporządzonej w styczniu 1955 r. dla potrzeb Wydziału Organizacyjnego Komitetu Centralnego Polskiej Zjednoczonej Partii Robotniczej - notatce o nadsyłanych przez komitety wojewódzkie meldunkach o nastrojach społecznych informowano, że w woj. kieleckim „ludność komentuje fakt nadawania przez radio kolęd, widząc w tym zapowiedź jakiś zmian" ${ }^{5}$. Niezbyt daleka przyszłość miała pokazać, że przeczucia te okazały się trafne.

Nawiasem mówiąc, trudno powiedzieć, co w większym stopniu: nienadawanie w radiu kolęd czy też silna indoktrynacja dzieci już w przedszkolach i w najmłodszych klasach szkół podstawowych, powodowało zabawne pomyłki, do jakich dochodziło w czasie wspólnego kolędowania w rodzinach. W 2009 r. Teresa Bogucka wspominała taką oto sytuację sprzed blisko sześćdziesięciu lat: „W Makowie Podhalańskim, gdzie mieszkałam, było przedszkole prowadzone przez zakonnice. No i te zakonnice już były mocno naciskane [przez władze] i poddawane takim sprawdzającym testom. Przychodziłam naładowana bolszewizmem z tego przedszkola. Mój dziadek pomstował po prostu, że to absolutny skandal. [--] kiedyś przy śpiewaniu kolęd wybuchła awantura, ponieważ zaśpiewałam «Maria Panna, Maria Panna dzieciątko piastuje, a Józef Stalin, a Józef Stalin ono pielęgnuje». Więc rodzina po prostu dostrzegła, że się coś tutaj pomieszało, babcia patriotyczna zrobiła straszliwą awanturę mojej mamie, że do czego jest to

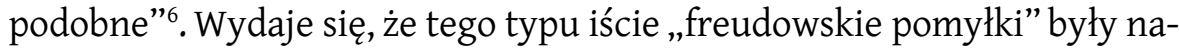
stępstwem nie tylko gwałtownej presji propagandowej, dotykającej - jak

${ }^{5}$ Cyt. za: Z. Rykowski, W. Władyka, Polska próba. Październik '56, Kraków 1989, s. 87.

${ }^{6}$ P. Osęka, My, ludzie z Marca. Autoportret pokolenia '68, Wołowiec 2015, s. 68. Ciekawe, że nie był to przypadek odosobniony. Marek Jodłowski wspominał, jak to w dzieciństwie „kościół rozbrzmiewał śpiewem kolęd. Grzmiały organy, pohukiwali mężczyźni, srebrzystą nić melodii adorowały kobiety. Spod plafonu dobiegały słowa: «I Józef Stalin i Józef Stalin jemu kolęduje» [--]. Zdziwiło mnie to, ale nie za bardzo. Dopiero później zrozumiałem, że to ja sam Józefa Starego zastąpiłem generalissimusem”. Cyt. za: R. Kupiecki, „Natchnienie milionów”. Kult Józefa Stalina w Polsce 1944-1956, Warszawa 1993, s. 139. 
widać - także najmłodszych, ale również chyba konsekwencją oddziaływania na ich podświadomość.

Dzisiaj stosunkowo często można usłyszeć, że Europa w coraz większym stopniu i coraz szybciej ulega procesom laicyzacji i/lub sekularyzacji. Trudno jednoznacznie rozstrzygnąć, czy jest to pogląd w pełni słuszny. Zanim jednak spróbuję odpowiedzieć na to pytanie, jeszcze na dwie rzeczy chciałbym najpierw zwrócić uwagę. Należy zatem przypomnieć, że w całej Europie od Portugalii po Rosję i od Norwegii po Grecję na karetkach pogotowia ratunkowego widnieje Czerwony Krzyż, a w wypadku wojennego zagrożenia znakiem tym, umieszczonym w widocznych miejscach (na przykład na dachach), oznacza się wszelkie obiekty służby zdrowia, takie jak szpitale, karetki pogotowia, pociągi i statki sanitarne. Tak czyniono również w Trzeciej Rzeszy, a nawet w stalinowskim Związku Radzieckim, gdzie na obiektach i pojazdach medycznych nie umieszczano przecież, odpowiednio, swastyk ani czerwonych gwiazd, lecz znak Czerwonego Krzyża. Oczywiście nie ma żadnej pewności, czy ktokolwiek kiedykolwiek w ZSRR zastanawiał się nad źródłem pochodzenia i symbolicznym znaczeniem tego znaku, zaczerpniętego z szeroko rozumianej tradycji chrześcijańskiej ${ }^{7}$. Przecież w krajach islamskich (a nawet w położonych na południu radzieckich republikach azjatyckich) analogicznie na obiektach i pojazdach należących do służby zdrowia umieszczano Czerwony Półksiężyc, w Izraelu zaś Czerwoną Gwiazdę Dawida ${ }^{8}$.

Po drugie, chciałbym przypomnieć, że w wielu państwach europejskich, w tym oczywiście także i w Polsce, najwyższe odznaczenia państwowe, a zwłaszcza wielce zaszczytne ordery bojowe mają kształt krzyży, by odwołać się do Virtuti Militari czy Krzyża Walecznych. Można przypuszczać, że podobnie jak w wypadku Czerwonego Krzyża, wykorzystywanego jako pewien bardzo czytelny symbol przez najrozmaitsze służby medyczne powołane do ratowania ludzkiego zdrowia i życia, ale z konieczności

${ }^{7}$ Źródła jego pochodzenia były zresztą bardziej złożone, wszak nie tylko chrześcijaństwo odwoływało się do symboliki krzyża. Zwykle zwracano także uwagę na fakt, że symbol Czerwonego Krzyża na białym tle został przyjęty prawnie wraz z uchwaleniem w roku 1864 Konwencji Genewskiej o „polepszeniu losu rannych w armiach czynnych”. W czasie jego przyjmowania wzorowano się na „odwróconej” fladze Szwajcarii: biały krzyż na czerwonym tle, nawiązującej zresztą do oznaczeń bitewnych Szwajcarów z późnego średniowiecza.

${ }^{8}$ Mając świadomość religijnych konotacji poszczególnych tych znaków, począwszy od 2007 r. zaczęto wprowadzać do prawa międzynarodowego nowy znak ochronny: Czerwony Kryształ, nie kojarzący się ani z chrześcijaństwem, ani z islamem, ani z judaizmem, ani z żadną inną religią. Miał on nie tyle zastąpić znaki istniejące wcześniej, ile funkcjonować obok nich. Trudno jeszcze wyrokować, gdzie, kiedy i w jakim zakresie on się przyjmie. 
niestety stykające się też dość często (szczególnie w czasie wojny) ze śmiercią i transcendentną granicą między dwoma światami, krzyże wojenne (niejednokrotnie przecież także przyznawane pośmiertnie) również mają nawiązywać do chrześcijańskiej tradycji cierpienia i ofiary.

Najwyższa jednak pora przejść do przykładu Polski Ludowej i przyjrzeć się nieco bliżej relacjom łączącym, a raczej dzielącym, rządzących komunistów i katolików, zwłaszcza katolickie duchowieństwo. Nie chodzi przy tym o wielokrotnie i niekiedy nader szczegółowo i na różne sposoby opisywane stosunki Kościół-państwo w okresie rządów komunistycznych ${ }^{9}$, ale o samo zderzenie dwóch krańcowo odmiennych wizji świata. Niezależnie bowiem od zachodzących po drodze rozmaitych „przymrozków i odwilży”, które przyczyniały się do pewnych zmian w tym zakresie, jak najszerzej rozumiany antyklerykalizm niemal przez cały czas był jednym $\mathrm{z}$ fundamentów władzy komunistycznej. Niezależnie od wszelkich taktycznych różnic dzielących poszczególne ekipy polityczne, niemal stale (może z wyjątkiem dziesięciu ostatnich lat) relacje na linii państwo-Kościół układały się źle lub bardzo źle. Jedynie w pierwszych trzech latach Polski Ludowej oraz na przełomie lat 1956-1957 z doraźnych powodów taktycznych komuniści powstrzymywali swoje zapędy nie tyle laicyzujące państwo i społeczeństwo, ile prowadzące do całkowitej ateizacji życia publicznego.

Dopiero po wyborze kardynała Karola Wojtyły na papieża zaszły pewne trwałe ${ }^{10}$ - jak pokazała przyszłość - zmiany w tym zakresie. Wszelako okoliczności towarzyszące kolejnym papieskim pielgrzymkom do Polski

${ }^{9}$ Z literatury przedmiotu, obejmującej już setki najróżniejszych publikacji książkowych na ten temat, tytułem przykładu należy tutaj przywołać następujące opracowania syntetyczne: A. i A. Anusz, Samotnie wśród wiernych. Kościót wobec przemian politycznych w Polsce (1944-1994), Warszawa 1994; A. Dudek, R. Gryz, Komuniści i Kościół $w$ Polsce (1945-1989), Kraków 2003; B. Fijałkowska, Partia wobec religii i Kościoła $w$ PRL, t. 1 : 1944-1955, Olsztyn 1999, t. 2, cz. 1: 1956-1963, Olsztyn 2000, t. 2, cz. 2: 1964-1970, Olsztyn 2001; Z. Zieliński, Kościół w Polsce 1944-2002, Radom 2003; J.Żaryn, Dzieje Kościoła katolickiego w Polsce (1944-1989), Warszawa 2003. Przedwcześnie zmarła Barbara Fijałkowska nie ukończyła swojego dzieła i tom trzeci (zarazem ostatni), obejmujący lata 19711989, nie został opublikowany. Zresztą książka ta nie jest klasyczną syntezą, ma bowiem wiele cech wydawnictwa źródłowego, a w każdym tomie 25-30 proc. tekstu zajmują dokumenty proweniencji partyjnej. Z prac nowszych patrz album: Ł. Marek, M. Bortlik-Dźwierzyńska, Za Marksem bez Boga. Laicyzacja życia społecznego w Polsce w latach 1945-1989, Katowice 2014.

${ }^{10}$ Wydarzeniem bez precedensu, mimo że o charakterze jednorazowym, ale o niezwykłym zasięgu społecznym, była przeprowadzona w niedzielę 22 października 1978 r. bezpośrednia telewizyjna transmisja z Rzymu z inauguracji pontyfikatu Jana Pawła II. W ten sposób Telewizja Polska po raz pierwszy w swojej ponad dwudziestoletniej wówczas historii przeprowadziła transmisję mszy świętej. Miliony Polaków mogły też wtedy wysłuchać po raz pierwszy wypowiedzianych po polsku przez Ojca Świętego słów pozdrowienia dla rodaków. 
w latach 1979, 1983 i 1987, z dzisiejszej perspektywy muszą budzić niesmak i zdumienie, świadcząc raczej o próbach kontynuacji wcześniejszych zasad "gry” z Kościołem. Za każdym bowiem razem władze państwowe starały się te pielgrzymki maksymalnie odsunąć w czasie; za każdym też razem zdecydowanie ingerowały w czas ich trwania i trasę, a wyraźnie miały też ochotę ingerować w teksty papieskich homilii. Wystarczy przypomnieć, iż w 1983 r. nie zgodziły się, aby Ojciec Święty odwiedził najsilniej związane z „Solidarnością” miasta Wybrzeża: Gdańsk, Gdynię i Szczecin. Trudno także komuś, kto to widział, zapomnieć sposób relacjonowania tych trzech pielgrzymek w Telewizji Polskiej.

Przede wszystkim starano się nieudolnie przekonywać społeczeństwo, że na przykład w 1979 r. kolejne msze i uroczystości z udziałem Jana Pawła II - poza Warszawą, Krakowem i Oświęcimiem (Auschwitz) mają wymiar lokalny i dlatego były prezentowane wyłącznie w regionalnych pasmach programowych, na przykład Gniezno tylko w Wielkopolsce, Częstochowa na Śląsku i w Zagłębiu Dąbrowskim itd. Ponadto w czasie wszystkich tych trzech pielgrzymek bez skrupułów manipulowano obrazem: kamerzyści mogli pokazywać głównie modlących się księży, zakonnice, ludzi starszych i to wyłącznie w planach zbliżeniowych - panoramowanie i ukazywania w prawdziwym wymiarze zgromadzonych tłumów było surowo zabronione. $Z$ drugiej strony należy jednak pamiętać, że w zgodzie z filozofią pecunia non olet w 1979 r. Telewizja Polska zrealizowała w kolorze - przeznaczone dla zachodnich widzów i za dewizy sprzedawane zagranicznym stacjom telewizyjnym - materiały filmowe wiernie oddające charakter spotkań Jana Pawła II z rodakami.

Rozwój wydarzeń w Polsce spowodował, że w latach osiemdziesiątych Kościół katolicki pełnił rolę moderatora, a czasem i pośrednika w kontaktach między władzą a „Solidarnością”. Jednocześnie cieszył się większą nieco swobodą niż w poprzednich okresach, zwłaszcza w zakresie budownictwa sakralnego i prowadzenia działalności wydawniczej. Relacje z władzą państwową dalekie były jednak od normalnych. Trudno zapomnieć, że podobnie jak w poprzednich latach działał Urząd do Spraw Wyznań, a za kulisami - Departament IV Ministerstwa Spraw Wewnętrznych, który właśnie w latach osiemdziesiątych dopuścił się swoich najgłośniejszych zbrodni. Dla milionów Polaków symbolem tzw. działalności dezintegracyjnej „resortu" już na zawsze pozostało porwanie i zamordowanie ks. Jerzego Popiełuszki.

Dopiero w maju 1989 r. władze PRL ostatecznie uregulowały prawnie swoje relacje z Kościołem katolickim i zdobyły się na nawiązanie oficjalnych stosunków dyplomatycznych ze Stolicą Apostolską. Z czasem, ale to już w czasie rządów Tadeusza Mazowieckiego, doprowadzono do 
likwidacji Urzędu do Spraw Wyznań oraz - wraz z rozwiązaniem Służby Bezpieczeństwa - także komórek w strukturach MSW, zajmujących się zwalczaniem Kościoła. Wydaje się jednak, że relatywnie wielu polityków III RP wywodzących się z PZPR nie wyzbyło się ostatecznie swoich antyklerykalnych uprzedzeń. Świadczyć o tym może na przykład fakt blokowania w Sejmie procesu ratyfikacji konkordatu przez cały okres rządów koalicji Sojuszu Lewicy Demokratycznej i Polskiego Stronnictwa Ludowego w latach 1993-1997. Gwoli naukowej rzetelności należy wszakże dodać, że z różnych powodów, zapewne także politycznych i koniunkturalnych, konkordat ostatecznie podpisał 23 lutego 1998 r. - wywodzący się z SLD prezydent Aleksander Kwaśniewski. W III RP stosunki między Kościołem a władzą państwową na ogół jednak oficjalnie układały się w oparciu o zasadę tzw. przyjaznej neutralności i nigdy - nawet w najgorszych dla nich momentach - nie zbliżyły się do poziomu... z najlepszych lat PRL.

Trudno jednak rozstrzygnąć, w jakim stopniu antyklerykalne nastawienie części lewicy w III RP pozostaje następstwem ideologicznych dogmatów z czasów PRL. W komunizmie na poczesnym miejscu umieszczono bowiem walkę z religią, co w wypadku Polski Ludowej oznaczało przede wszystkim konfrontację z Kościołem katolickim, rozumianym głównie jako instytucja, a nie wspólnota wiernych. Towarzyszyła temu walka z duchowieństwem oraz religią traktowaną jako „opium dla ludu"11. Ciekawe, że po latach stosunkowo wielu moich rozmówców z kręgów byłych działaczy partyjnych bardzo krytycznie wypowiadało się na temat tej ,,antyklerykalnej obsesji", uważając ją za poważny błąd i jedną z istotnych przyczyn porażki własnej formacji w wymiarze historycznym. Ich zdaniem walka z Kościołem w katolickim w swej masie społeczeństwie była z góry skazana na niepowodzenie.

Rzeczywiście, chociaż niemało już na ten temat wiemy, ciągle zdumiewa, jak wiele środków, czasu i energii (niezależnie od „etapu historyczne-

11 Ostatni I sekretarz KC PZPR Mieczysław F. Rakowski w rozmowie z Dariuszem Wilczakiem zwracał uwagę na to, że ten cytat z Karola Marksa sfałszowano: „To jest tylko połowa zdania: «Religia jest opium dla ludu». Dalej jest: «Religia jest nadzieją uciśnionych tego świata»”. D. Wilczak, Mucha za szyba. Nie dokończona rewolucja, Warszawa 1997, s. 73. Rakowski też do końca nie był jednak precyzyjny, a jego interpretacja nieco zamazuje sens tego, co w istocie napisał Marks. Zob.: K. Marks, Przyczynek do krytyki heglowskiej filozofii prawa. Wstęp (po raz pierwszy opublikowane: „Deutsch-Französische Jahrbücher", 1844; w języku polskim po raz pierwszy opublikowane: K. Marks, F. Engels, Wybrane pisma filozoficzne 1844-1846, Warszawa 1949). Czytamy zatem u Marksa: „Religia jest westchnieniem uciśnionego stworzenia, sercem nieczułego świata, jest duszą bezdusznych stosunków. Religia jest opium ludu”. I dalej: „Prawdziwe szczęście ludu wymaga zniesienia religii jako urojonego szczęścia ludu". To znamienna różnica, którą wprowadzili bolszewicy, zmieniając tym samym sens oryginalnej idei Marksa („opium dla ludu” zamiast „opium ludu”). 
go") komuniści w Polsce poświęcali na walkę z katolicyzmem, a przecież na tym polu - zarówno gdy chodzi o rezultaty, jak i włożony wysiłek - nigdy nie mogli równać się ze swoimi towarzyszami z innych państw realnego socjalizmu. Co gorsza dla nich, przez cały czas byli krytykowani przez „towarzyszy radzieckich" i przedstawicieli innych „,bratnich partii” zarzucających im, że nie dość stanowczo walczą z przejawami klerykalizmu w życiu publicznym - jak zazwyczaj określano prowadzoną w Polsce bardziej liberalną politykę wobec Kościoła katolickiego.

W tym miejscu warto przypomnieć, że John Connelly zwrócił uwagę na wymowny paradoks: „Na ironię zakrawa - pisał - że ocena Czesława Miłosza, głosząca, że po wojnie religia utraciła w Europie swoje wpływy, jest prawdziwa niemal wszędzie poza jego własnym krajem. Bardziej niż kiedykolwiek, Kościół w Polsce był tam uważany za bastion narodowej kultury. Zniszczenie w czasie wojny dawnego kierownictwa i szeroki udział księży w zdecentralizowanych strukturach podziemia doprowadziły do rozluźnienia więzi między Kościołem i państwem i większego niż kiedykolwiek stopnia konwergencji między poglądami i wartościami kleru i społeczeństwa"12.

Relacje Kościół-państwo w Polsce Ludowej różnie kształtowały się w różnych latach: były okresy lepsze, były gorsze - nigdy jednak stosunki te nie były w pełni szczere i lojalne. Aż do 1989 r. komuniści ostatecznie nie zrezygnowali ze stosowania metod o charakterze terrorystycznym. Wystarczy przypomnieć uprowadzenie i zamordowanie ks. Jerzego Popiełuszki w 1984 r. przez trzech oficerów Departamentu IV, jak i co najmniej tajemnicze zgony księży: Stefana Niedzielaka, Stanisława Suchowolca i Sylwestra Zycha w 1989 r. Dzięki badaniom prowadzonym na szeroką skalę w Instytucie Pamięci Narodowej wiemy dziś również, że żadna grupa zawodowa czy społeczna w PRL nie była poddana aż takiej inwigilacji ze strony aparatu bezpieczeństwa jak właśnie duchowieństwo.

Jest przy tym zrozumiałe, że tak przedstawiciele władz państwowych, jak i reprezentanci strony kościelnej mieli zupełnie przeciwstawne interesy i chcieli realizować krańcowo odmienne wizje wzajemnych stosunków. Można powiedzieć, że strona partyjno-państwowa - mimo różnych zawirowań i wahań - przez cały czas dążyła do podporządkowania sobie hierarchii katolickiej, a gdy okazywało się to niemożliwe, to przynajmniej do maksymalnego ograniczenia roli Kościoła w życiu publicznym. Ten z kolei stale bronił się przed uszczuplaniem sfery oddziaływania katolicyzmu na społeczeństwo. Niekiedy jednak, w zamian za określone koncesje i ustęp-

${ }^{12} \mathrm{~J}$. Connelly, Zniewolony uniwersytet. Sowietyzacja szkolnictwa wyższego w Niemczech Wschodnich, Czechach i Polsce. 1945-1956, Warszawa 2014 (oryg. ang. 2000), s. 118. 
stwa, skłonny był taktycznie w pewnych działaniach zachować neutralność lub wręcz popierać komunistów. Czasem wywalczane w ten sposób zdobycze były istotne i ważne także dla społeczeństwa (na przykład w zakresie nauczania religii w szkołach czy swobody działalności religijnej w środowiskach zamkniętych: szpitalach, wojsku, więzieniach, na obozach i koloniach dla dzieci), czasem wyłącznie dla Kościoła jako instytucji (na przykład ulgi czy zwolnienia podatkowe lub celne).

Zresztą w ciągu kilkudziesięciu lat Kościół katolicki w Polsce dwukrotnie stanął w obliczu gruntownych przemian ustrojowych. Po raz pierwszy, gdy w latach 1944-1945 był świadkiem zdobywania władzy przez komunistów, co dokonywało się - jak wiadomo - w decydującym stopniu za sprawą potęgi militarnej Związku Radzieckiego, którego miliony żołnierzy wyzwalały Polskę spod okupacji niemieckiej, równocześnie „zabezpieczając” proces tworzenia - opartej w bardzo znacznym stopniu (choć nie wyłącznie) na przemocy i terrorze - komunistycznej dyktatury. Po raz drugi, w końcu lat osiemdziesiątych, gdy dożywał dni system monocentryczny, a na jego gruzach formowało się państwo demokratyczne.

Jest przy tym zrozumiałe, że w PRL, gdzie stale ponad 90 proc. społeczeństwa określało się mianem katolików, choć nieporównanie mniej osób aktywnie uczestniczyło w życiu religijnym i żyło zgodnie z nakazami wiary, siłą rzeczy także członkowie, a czasem nawet aktywiści PZPR - mniej czy bardziej regularnie - uczęszczali do kościoła. Było to źle widziane przez władze partyjne, zwłaszcza w okresie stalinowskim, gdy PZPR w relatywnie największym stopniu miała charakter partii komunistycznej. Ale nie tylko wtedy tego typu „klerykalne” zachowania (także członków najbliższej rodziny) szczególnie piętnowane i zwalczane były w „resortach siłowych”: wojsku, milicji i aparacie bezpieczeństwa oraz wśród przedstawicieli administracji i wśród kadry kierowniczej. We wszystkich tych środowiskach nierzadkie były potajemne śluby, chrzty dzieci i ich pierwsze komunie w kościołach odległych niekiedy nawet o wiele kilometrów od miejsca zamieszkania, a czasem wręcz w innych miastach. Jednak najpoważniejszym problemem, z czasem także dla wielu działaczy z kierownictwa partyjnego, były kościelne pogrzeby członków najbliższej rodziny - zwłaszcza pochówki wierzących i praktykujących rodziców ${ }^{13}$.

Wojciech Jaruzelski w rozmowie z Teresą Torańską wspominał, że w 1966 r. w czasie pogrzebu matki nie wszedł do kościoła: „Byłem wtedy

${ }^{13}$ Ten kompleks spraw - jak dotychczas - najdokładniej przebadał i opisał Krzysztof Kosiński. K. Kosiński, „Religianctwo”. Napięcie między ideologia a religia w świadomości członków i działaczy PZPR, „Polska 1944/45-1989. Studia i materiały” 12, 2014, s. 107-203. 
szefem Sztabu Generalnego i wiceministrem obrony narodowej. [- - Nie miałem wątpliwości, że pojadę. Ale to był katolicki pogrzeb. Moja matka była osobą głęboko wierzącą. [- - Przed wyjazdem rozmawiałem z ministrem obrony narodowej marsz. Spychalskim. Poinformowałem go, że chcę jechać. [- - ] na drugi dzień i tak miałby na biurku informację, że gen. Jaruzelski był na katolickim pogrzebie. Uznałem, że będzie lepiej, gdy otrzyma ją wcześniej i ode mnie. Odpowiedział: «No, cóż, to jest wasza decyzja, ale rozumiecie, że my w wojsku nie zachęcamy naszych oficerów do uczestnictwa w uroczystościach religijnych»". Gen. Jaruzelski dodał, że był na pogrzebie po cywilnemu. „Zrobiłem jeden krok, że na pogrzeb pojechałem, że byłem na cmentarzu i de facto uczestniczyłem w religijnym pochówku mojej matki, ale nie zrobiłem drugiego kroku nie wszedłem do kościoła”, gdyż „byłoby to nielojalne wobec Spychalskiego i kierownictwa resortu. Oraz niemoralne w stosunku do podwładnych, wobec których istniały zasadnicze przeciwwskazania uczestniczenia w podobnych uroczystościach"14.

Z czasem zresztą w miejsce religijnych - obok ślubów i pogrzebów wprowadzono także świeckie uroczystości nadania dzieciom imion, będące laickim odpowiednikiem chrztu. Tak było na przykład w 1971 r., gdy przyszły na świat popularne „gdańskie pięcioraczki”. Ponieważ ich ojciec był zawodowym żołnierzem, a jednocześnie władzom chodziło o podkreślenie świeckości Ludowego Wojska Polskiego, zorganizowano w gdańskim Dworze Artusa - utrwaloną na kolorowej taśmie w filmie dokumentalnym - uroczystość nadania dzieciom imion. Ich opiekunami (ateistycznymi odpowiednikami ojców chrzestnych) zostali między innymi premier Piotr Jaroszewicz i minister obrony narodowej gen. Jaruzelski.

W sytuacji, gdy komuniści systematycznie dążyli do laicyzacji i ateizacji życia publicznego, rola Kościoła katolickiego była niezwykle trudna. Przez cały czas był on tą siłą, która najskuteczniej - choć również nie zawsze do końca - opierała się naciskom władz państwowych. Ponadto dla wielu ludzi był depozytariuszem tradycji narodowej i - w jakimś przynajmniej stopniu - rzecznikiem interesów katolickiego w większości społeczeństwa. Jest zrozumiałe, że nie wszyscy jednak tak patrzyli (i patrzą nadal) na tę kwestię.

Wystarczy w tym miejscu przypomnieć, jak politykę władz PRL wobec Kościoła katolickiego u schyłku XX w. oceniał były kierownik Urzędu do Spraw Wyznań z lat 1982-1987, prof. nauk prawnych Adam Łopatka: „Polityka PPR i PZPR w stosunku do Kościoła katolickiego, a także innych Kościołów i związków wyznaniowych, była dyktowana interesa-

${ }^{14}$ T. Torańska, Byli, Warszawa 2006, s. 31. 
mi Polski Ludowej. Była również korzystna dla Kościołów i związków wyznaniowych. [- - ] Była to polska oryginalna polityka. Nawiązywała do demokratycznych doświadczeń innych państw, w szczególności USA i Francji. Polityka ta doceniała zawsze wartości wnoszone przez Kościół do życia narodu: jego rolę w zaspokajaniu potrzeb religijnych ludzi wierzących, rolę kulturotwórczą w dziedzinie architektury, sztuki, muzyki, śpiewu i literatury. Doceniała również wielką rolę Kościoła w zagospodarowywaniu kulturalnie wolnego czasu. Także rolę kościelnej doktryny moralnej w kształtowaniu stosunków między ludźmi oraz rozwijaniu pokojowych stosunków międzynarodowych. Państwo ludowe nigdy nie próbowało ingerować, a nawet tylko wypowiadać się na temat wierzeń czy obrzędów i ceremonii oraz rytuałów religijnych. [- - ] Była to polityka poszanowania potrzeb religijnych ludzi wierzących, wolności sumienia i wyznania. Nie była nigdy antyreligijna"15.

Trudno wprost uwierzyć, że coś tak absurdalnego i nieprawdziwego mógł napisać - jak wynika z biogramu zamieszczonego w cytowanej książce - naukowiec rangi międzynarodowej. Prawienie o wolności sumienia i wyznania w PRL, o docenianiu przez rządzących kulturotwórczej roli Kościoła katolickiego w dziedzinie architektury (czyżby autor tych słów miał na myśli przyznawanie lub może raczej nieprzyznawanie „po uważaniu” zezwoleń na budowę nowych kościołów?) czy też przekonywanie,że Polska Ludowa nigdy nie próbowała ingerować w sprawowanie kultu - zwłaszcza w kontekście działalności Urzędu do Spraw Wyznań oraz Departamentu IV MSW - zakrawa na ponury żart!

Zresztą we wzajemnych relacjach Kościół-państwo można wyróżnić kilka podokresów. Jak już wspomniano, paradoksalnie stosunki te były relatywnie najlepsze w okresach początkowym i końcowym Polski Ludowej. W pierwszych latach Polska Partia Robotnicza, korzystając z radzieckiego „parasola ochronnego”, oficjalnie głosząc umacnianie się systemu demokratycznego, stopniowo zyskiwała pozycję hegemona w życiu publicznym. W ramach zastosowanej przez komunistów w państwach bloku wschodniego tzw. taktyki salami ${ }^{16}$, polegającej na stopniowym (,plasterek po plasterku") eliminowaniu ze sceny politycznej kolejnych sił, grup, organizacji, ze względów taktycznych do 1948 r. unikano otwartego atakowania katolicyzmu i Kościoła, chociaż konkordat został zerwany przez nowe władze już we wrześniu 1945 r. Komuniści w tym pierwszym okresie starali się

${ }^{15}$ A. Łopatka, Polityka PZPR wobec Kościoła katolickiego, w: Polska pod rządami PZPR, red. M.F. Rakowski, Warszawa 2000, s. 248-249.

${ }^{16}$ Autorem określenia „taktyka salami” był Mátyás Rákosi, komunistyczny dyktator Węgier i sekretarz generalny Węgierskiej Partii Robotniczej, który uważał się za „najwierniejszego ucznia Stalina”. 
zachowywać coś więcej niż tylko pozory i deklarowali chęć utrzymania wolności religijnych w Polsce ${ }^{17}$.

Co więcej, gdy była taka potrzeba („na danym etapie”), dygnitarze komunistyczni, w tym i sam przewodniczący Krajowej Rady Narodowej Bolesław Bierut, uczestniczyli w świętach i uroczystościach kościelnych. W 1944 r. Dzień Wojska Polskiego obchodzono jeszcze tak jak przed wojną, 15 sierpnia w rocznicę zwycięstwa w Bitwie Warszawskiej w 1920 r., a zarazem w dniu święta Wniebowzięcia Najświętszej Marii Panny ${ }^{18}$. Tego dnia po raz pierwszy odbyło się w Lublinie posiedzenie KRN. W trakcie obrad ogłoszono przerwę, żeby zebranym umożliwić uczestniczenie w uroczystej mszy polowej, w której obok Bieruta, przewodniczącego Polskiego Komitetu Wyzwolenia Narodowego Edwarda Osóbki-Morawskiego i innych dygnitarzy uczestniczył także przedstawiciel ZSRR Nikołaj Bułganin (Nikolaj Aleksandrovič Bulganin) ${ }^{19}$.

Jednocześnie władze wielokrotnie przekonywały wówczas społeczeństwo, że swobody religijne w żadnym razie nie będą zagrożone. Polskie Radio w niedziele i święta transmitowało jeszcze msze, a program każdego dnia rozpoczynała religijna pieśń Kiedy ranne wstaja zorze. W uroczystościach oddawania do użytku odbudowanych czy nowo zbudowanych obiektów użyteczności publicznej obok przedstawicieli władz państwowych niemal zawsze uczestniczyli odpowiedni do rangi wydarzenia duchowni katoliccy. Nie inaczej było w czasie różnych ważnych uroczystości. Ale już w tym samym czasie Bierut w trakcie prowadzonych w Belwederze rozmów ze swoim sekretarzem prasowym Stanisławem Łukasiewiczem bardzo ostro atakował duchowieństwo.

Ten ostatni tak po latach zrelacjonował słowa swojego przełożonego: „Proboszcz wiejski jest główną podporą ciemnogrodu w naszym kraju, polski kler jest zacofany, i ma, niestety, w dalszym ciągu ogromny wpływ na masy. On, Bierut, nieraz się przekonał na własnej skórze, jak proboszczowie wiejscy potrafią być chciwi i niedobrzy". Dodał jednak od razu: „Ale wcale nie będziemy prześladowali Kościoła w Polsce [--] choć może księża by tego chcieli. Naród polski jest katolicki, przywiązany do swojej wiary, łączą się z tym różnego rodzaju formy obyczajowe, święta, obrzędy, śpiewy, nawet stroje. Katolickie wierzenia w Polsce stały się już jakąś

${ }^{17}$ Na ten temat szerzej zob. J. Żaryn, Kościół a władza w Polsce (1945-1950), Warszawa 1997.

${ }^{18}$ W wojsku służyli zresztą księża kapelani, a przysięga żołnierska kończyła się słowami „Tak mi dopomóż Bóg”. Jeszcze w lutym 1947 r. tymi samymi słowami Bierut w Sejmie zakończył swoje prezydenckie ślubowanie.

${ }_{19}$ M. Łatyński, Nie paść na kolana. Szkice o polskiej polityce lat powojennych, Wrocław 2002, s. 664; T. Żenczykowski, Polska Lubelska 1944, Paryż 1987, s. 111-112. 
formą kultury polskiej. Byłoby więc nonsensem likwidować to wszystko. Przecież i ja muszę czasami chodzić do kościoła - uśmiechnął się". Wspomniał także, iż niedawno na procesji Bożego Ciała w Warszawie prowadził razem z marsz. Michałem „Rolą” Żymierskim pod ramię prymasa Augusta Hlonda.

Niemniej jednak - tłumaczył Bierut - „pogodzenie się z faktem istnienia w Polsce kleru katolickiego ze wszystkimi jego wpływami nie oznacza wcale, że powinniśmy zrezygnować z naszych koncepcji laickich, z naszego światopoglądu laickiego i z propagandy na rzecz takiego właśnie rozumienia świata. Nie możemy się przecież wyrzec wychowania młodzieży w duchu laickim, szczególnie w naszych szkołach, gdzie antydialektyzm, fideizm katolicki, a więc $\mathrm{w}$ istocie myślenie ogłupiające, tak mocno zapuściło korzenie, choćby w okresie dwudziestolecia. $\mathrm{O}$ to, że chcemy szerzyć naszą propagandę laicką, udrapowana w różne świętości reakcja ma również do nas wielkie pretensje. W Polsce publicznie można propagować tylko poglądy religijne, katolickie - mówił dalej" ${ }^{20}$. Jak widać, Bierut miał poglądy bardzo jednostronne i zdecydowanie niesprawiedliwe wobec katolików. Była to jednak w obozie politycznym sprawującym władzę tendencja stała, nie ograniczająca się wyłącznie do pierwszych lat Polski Ludowej.

Wszelako choć komuniści niejednokrotnie już wcześniej zarzucali biskupom „popieranie reakcji”, sugerując istnienie związków hierarchii katolickiej z opozycją parlamentarną, a nawet ze zbrojnym podziemiem, to jednak na ogół do 1948 r., kiedy to w praktyce zakończono w Polsce pierwszy etap budowy systemu komunistycznego w jego stalinowskim wydaniu, powstrzymywali się przed frontalnymi atakami i unikali otwartych konfliktów ${ }^{21}$. Przypadek sprawił, że to zaostrzenie kursu wobec Kościoła zbiegło się w czasie ze śmiercią prymasa Hlonda. Jego następcą został czterdziestosiedmioletni wtenczas biskup lubelski Stefan Wyszyński. Był to człowiek rozumiejący dokonujące się zmiany, co oczywiście nie znaczy, że je akceptujący. Miał on w sobie zarazem coś z reformatora i konserwatysty, ale przede wszystkim okazał się trudnym i wymagającym przeciwnikiem dla komunistów.

${ }^{20}$ S. Łukasiewicz, Byłem sekretarzem Bieruta. Wspomnienia z pracy w Belwederze $w$ latach 1945-1946, Kraków 1987, s. 40.

${ }^{21}$ Niemniej jednak Krystyna Trembicka w swoich analizach podkreślała, że „władze komunistyczne od początku istnienia Polski Ludowej traktowały Kościół katolicki jako wroga”, z którym z „różnym natężeniem” prowadziły walkę, przy czym kolejne odsłony tej walki (jej intensywność, skala, czas trwania itp.) zależały zawsze od strony partyjno-państwowej, K.W. Trembicka, Wrogowie w myśli politycznej Polskiej Zjednoczonej Partii Robotniczej, Lublin 2013, s. 136-154. 
Jednocześnie był człowiekiem, który w bardzo udany sposób potrafił połączyć przypisany jego stanowisku autorytet formalny $z$ autorytetem nieformalnym, na który już sam zapracował w czasie sprawowania posługi prymasowskiej. Na pewno budowaniu tego autorytetu sprzyjał fakt, że był prymasem przez blisko 33 lata. W tym czasie wielokrotnie spotykał się z kolejnymi pierwszymi sekretarzami Komitetu Centralnego PZPR: od Bieruta po Stanisława Kanię. Na dwa miesiące przed swoją śmiercią - w czasie głębokiego kryzysu polityczno-społecznego w marcu 1981 r. - kard. Wyszyński rozmawiał z będącym od kilku tygodni premierem gen. Jaruzelskim, który pół roku później także został I sekretarzem KC PZPR. Być może właśnie ze względu na te kontakty z partyjnymi przywódcami prymas tak dobrze, jak może nikt inny z kręgów kościelnych, znał i rozumiał sposób myślenia komunistów.

Prawdopodobnie jednak w jeszcze większym stopniu budowaniu tego niezwykłego autorytetu prymasa sprzyjała jego niezłomna postawa w okresie stalinowskim oraz fakt uwięzienia go przez komunistów. I choć władze państwowe ostatecznie nie zdecydowały się na zorganizowanie pokazowego procesu, to jednak przez ponad trzy lata przetrzymywały go w izolacji bez sądowego wyroku, przy czym dopiero ostatnie miejsce pobytu - klasztor sióstr nazaretanek w Komańczy koło Sanoka - nie przypominało klasycznego aresztu. Prymas mógł też wreszcie, począwszy od jesieni roku 1955, kontaktować się ze światem zewnętrznym, od którego przez poprzednie dwa lata był w praktyce izolowany ${ }^{22}$.

Zanim jednak doszło do uwięzienia kard. Wyszyńskiego stosunki Kościół-państwo w Polsce zaczęły pogarszać się dosłownie z tygodnia na

22 Szerzej zob.: E.K. Czaczkowska, Kardynał Wyszyński. Biografia, Kraków 2013; A. Micewski, Stefan Kardynał Wyszyński (1901-1981), Warszawa 2000 (Jest to w praktyce niezmieniona wydana po raz pierwszy w roku 1982 w Paryżu książka Kardynał Wyszyński. Prymas i mąż stanu). Por. też P. Raina, Kardynał Wyszyński, t. 1: Droga na Stolicę Prymasowska, Warszawa 1993; idem, Kardynał Wyszyński, t. 2: Losy więzienne, Warszawa 1993; idem, Kardynał Wyszyński, t. 3: Czasy Prymasowskie 1956-1961, Warszawa 1994; idem, Kardynat Wyszyński, t. 4: Czasy Prymasowskie 1962-1963, Warszawa 1994; idem, Kardynał Wyszyński, t. 5: Czasy Prymasowskie 1964-1965, Warszawa 1996; idem, Kardynał Wyszyński, t. 6: Orędzie biskupów a reakcja władz, Warszawa 1995; idem, Kardynał Wyszyński, t. 7: Konflikty roku milenijnego, Warszawa 1998; idem, Kardynał Wyszyński, t. 8: Czasy prymasowskie 1967-1968, Warszawa 1998; idem, Kardynał Wyszyński, t. 9: Czasy Prymasowskie 1969-1970, Warszawa 2003; idem, Kardynał Wyszyński, t. 10: Czasy Prymasowskie 1971, Warszawa 2007; idem, Kardynał Wyszyński, t. 11: Czasy Prymasowskie 1972, Warszawa 2004; idem, Kardynał Wyszyński, t. 12: Czasy Prymasowskie 1973, Warszawa 2004; idem, Kardynat Wyszyński, t. 13: Czasy Prymasowskie 1974, Warszawa 2006; idem, Kardynał Wyszyński, t. 14: Czasy Prymasowskie 1975, Warszawa 2006; idem, Kardynał Wyszyński, t. 19: Czasy Prymasowskie 1980, Warszawa 2010. 
tydzień. Różne były przyczyny tego stanu rzeczy. Nie przypisując poszczególnym z nich mniejszej lub większej roli, należy wskazać na wspomniane już zakończenie kluczowego etapu politycznej (i w systematycznie malejącym stopniu także i zbrojnej) walki o władzę. Następstwem zwycięstwa komunistów w tej walce była nasilająca się z miesiąca na miesiąc akcja sowietyzacji, której przejawami były między innymi: kolektywizacja rolnictwa, forsowna industrializacja, proklamowanie w kulturze i sztuce realizmu socjalistycznego, monopolizacja ruchu młodzieżowego przez utworzenie Związku Młodzieży Polskiej oraz Powszechnej Organizacji „Służba Polsce”, ruch przodownictwa pracy itd.

Wszystkim tym posunięciom towarzyszyły nasilające się naciski ze strony coraz mocniej dzierżących władzę komunistów na stopniowo wypychane z przestrzeni publicznej duchowieństwo katolickie. Wydaje się zresztą, że nie tylko w owym czasie, ale praktycznie przez całe czterdzieści pięć lat głównym polem konfrontacji były wpływy jednej lub drugiej strony wśród młodzieży. Innymi słowy, była to walka o rząd dusz w Polsce $\mathrm{w}$ danym momencie, ale może $\mathrm{w}$ jeszcze większym stopniu w przyszłości. W takiej właśnie atmosferze w pierwszej połowie 1949 r. przez kraj przetoczyła się fala „spontanicznie” organizowanych manifestacji o charakterze antyklerykalnym. Równocześnie władze mnożyły konflikty o zasięgu lokalnym i ogólnokrajowym oraz domagały się od hierarchii katolickiej, żeby oficjalnie i otwarcie uznała nowy ustrój i wezwała do tego wiernych. Na dalsze pogorszenie się wzajemnych stosunków niewątpliwie wpłynął także fakt ogłoszenia przez papieża Piusa XII oświadczenia, grożącego ekskomuniką katolikom członkom i sympatykom partii komunistycznych.

Decyzji tej nie podano w Polsce do wiadomości publicznej, natomiast sprowokowała ona kontrakcję ze strony władz państwowych, które 5 sierpnia 1949 r. wydały dekret o ochronie „wolności sumienia i wyznania”, grożący między innymi więzieniem za - rozumiane przez rządzących w sposób zupełnie dowolny - „nadużywanie wolności wyznania i sumienia w celach wrogich ustrojowi”. Władze państwowe nie ukrywały też, iż zamierzają ingerować w życie wewnętrzne zgromadzeń zakonnych. Wydaje się, że wszystko to razem było elementem gry i formą nacisku na przedstawicieli Kościoła. W tym samym czasie - co tylko pozornie może wydawać się paradoksalne - trwały bowiem prowadzone w tajemnicy rozmowy między przedstawicielami władz państwowych a hierarchią katolicką, których celem było doprowadzenie do zawarcia porozumienia. Wszelako początkowo obie strony nie były skłonne do kompromisów. Przede wszystkim jednak władze państwowe dążyły do całkowitego podporządkowania sobie hierarchii kościelnej. 
We wrześniu 1949 r., przeprowadzając akcję łączenia istniejących dotychczas organizacji kombatanckich w jedną, monopolistyczną, która przybrała nazwę Związek Bojowników o Wolność i Demokrację, utworzono przy niej Komisję Księży, której członkami byli tzw. księża patrioci ${ }^{23}$. W styczniu 1950 r. rząd zdecydował się na kolejne posunięcie, które miało „zmiękczyć" nieustępliwych biskupów. W ten sposób należałoby odczytywać decyzję, na mocy której władze państwowe bezprawnie mianowały komisaryczny zarząd w Zrzeszeniu Katolików „Caritas” i przejęły około tysiąca zakładów opiekuńczych. Nasiliły się też aresztowania duchownych, dokonywane pod na ogół fikcyjnymi zarzutami. 20 marca Sejm uchwalił ustawę o przejęciu na własność państwa nieruchomości ziemskich należących do Kościoła (tzw. dobra martwej ręki). Równocześnie ogłoszono, że niepodporządkowanie się tej ustawie, traktowanej jako przedłużenie reformy rolnej z września 1944 r., będzie karane z całą surowością prawa - do kary śmierci włącznie. Być może to właśnie były najbardziej spektakularne przejawy sekularyzacji dóbr kościelnych w całym okresie Polski Ludowej. Wydawało się więc, że o żadnym porozumieniu Kościół-państwo nie może być mowy, jednak dość niespodziewanie 14 kwietnia 1950 r. zostało podpisane „Porozumienie między przedstawicielami rządu Rzeczpospolitej Polskiej i Episkopatu Polski" - pierwszy tego typu układ zawarty między komunistami sprawującymi władzę a hierarchią katolicką. Co ciekawe, Stolica Apostolska zachowała wobec dokumentu wyraźny dystans. Wynikało to zapewne z tego, że papież Pius XII nie do końca rozumiał specyfikę sytuacji Kościoła w rządzonym przez komunistów katolickim kraju ${ }^{24}$.

${ }^{23}$ Problematyka ta doczekała się już stosunkowo wielu publikacji. Zob.: B. Bankowicz, Ruch księży patriotów 1949-1955 czyli „koń trojański” w polskim Kościele katolickim, w: eadem, A. Dudek, Ze studiów nad dziejami Kościoła i katolicyzmu w PRL, Kraków 1996, s. 5-24; T. Markiewicz, „Księża patrioci” w latach 1949-1955, w: Stosunki między państwem a Kościołem rzymskokatolickim w czasach PRL, red. A. Chojnowski, M. Kula, Warszawa 1998; J. Stefaniak, „Księża patrioci” w latach 1945-1953, „Przegląd Powszechny” 1999, nr 3, s. 321-329; J. Żaryn, „Księża patrioci” - geneza powstawania formacji duchownych katolickich, „Polska 1944/45-1989. Studia i materiały” 1, 1995, s. 123-150; J. Żurek, Ruch „księży patriotów" w województwie katowickim w latach 1949-1956, Warszawa-Katowice 2009.

${ }^{24}$ Zob. J. Żaryn, Nieznany list prymasa polski Stefana Wyszyńskiego do Stolicy Apostolskiej w sprawie tzw. porozumienia z rzadem z 14 kwietnia 1950 roku, „Polska 1944/45-1989. Studia i materiały” 2, 1997, s. 291-308; idem, Stolica Apostolska wobec Polski i Polaków w latach 1944-1958 w świetle materiałów ambasady RP przy Watykanie (wybór dokumentów), Warszawa 1998; idem, Kościół w Polsce w latach przełomu (1953-1958). Relacje ambasadora RP przy Stolicy Apostolskiej, Warszawa 2000. Na temat polityki Stolicy Apostolskiej wobec państw Europy Środkowo-Wschodniej szerzej patrz: H.J. Stehle, Tajna dyplomacja Watykanu. Papiestwo wobec komunizmu 1917-1991, Warszawa 1993 (oryg. niem. 1993). Zob. też A. Casaroli, Pamiętniki - męczeństwo cierpliwości. Stolica Święta i kraje komunistyczne (1963-1989), Warszawa 2001 (oryg. wł. 2000). 
Z drugiej strony trudno nie zauważyć, że ustępstwa strony kościelnej były naprawdę poważne i miały daleko idące konsekwencje. Kościół zobowiązał się bowiem do nieprzeciwstawiania się kolektywizacji rolnictwa, miał wzywać wiernych do poszanowania „prawa i władzy państwowej”, deklarował wolę zwalczania „zbrodniczej działalności band podziemia” oraz przeciwstawiania się „wszelkim dążeniom do wywołania wojny". Były to niewątpliwie znaczne ustępstwa i trudno nie zauważyć, że decydując się na taką swoistą deklarację lojalności wobec rządzących, hierarchowie niemało ryzykowali. Liczyli przy tym najpewniej na bezgraniczne zaufanie i oddanie ze strony wiernych. Niemniej jednak część z nich - zwłaszcza tę lepiej wykształconą i zarazem jednoznacznie antykomunistyczną - wystawiali na ciężką próbę.

Wszelako Kościół uzyskiwał również istotne obietnice. Przede wszystkim miało być utrzymane nauczanie religii w szkołach, pod warunkiem jednak uzgadniania programów nauczania z władzami świeckimi ${ }^{25} . \mathrm{Za}$ chowano podstawową opiekę duszpasterską w więzieniach i szpitalach oraz gwarantowano możliwość organizowania tradycyjnych pielgrzymek i procesji. Jak się wydaje, biskupi, zawierając to porozumienie, chcieli także zyskać na czasie i jakoś „przeczekać” nadciągające coraz cięższe lata. Zapewne nie mieli przy tym złudzeń co do tego, że komuniści stale będą interpretować ten dokument w sposób jak najkorzystniejszy dla siebie samych i zarazem będą systematycznie ograniczać pole manewru Episkopatu.

Niemniej jednak do drastycznego pogorszenia się stosunków na linii Kościół-państwo doszło dopiero na przełomie lat 1952 i 1953. Wtedy władze państwowe odmówiły prymasowi paszportu na wyjazd do Rzymu, gdzie miał odebrać kardynalski kapelusz. Nasiliły się aresztowania duchownych, którym stawiano zarzuty natury politycznej (szpiegostwo lub działanie na szkodę państwa) bądź kryminalnej (rzekome kradzieże czy nadużycia). Kulminacyjnym momentem tej fazy konfliktu było wydanie przez władze 9 lutego $1953 \mathrm{r}$. dekretu o ,tworzeniu, obsadzaniu i znoszeniu duchownych stanowisk kościelnych", w myśl którego przed objęciem stanowiska kościelnego wymagana była akceptacja organów państwowych oraz złożenie ślubowania na wierność państwu w tym kształcie, w jakim ono wówczas funkcjonowało. Władze były już zresztą zdecydowane kontynuować zaostrzony kurs i w sposób radykalny rozprawić się z „niepokornymi” duchownymi. W końcu, 25 września 1953 r.,

${ }^{25}$ B. Kaliski, Walka władz o petna laicyzację szkolnictwa na przykładzie szkół archidiecezji gnieźnieńskiej, w: Władze wobec Kościołów i związków wyznaniowych w Wielkopolsce w latach 1945-1956, red. K. Białecki, Poznań 2008, s. 29-43. 
Kościół katolicki w Polsce dotknął najpoważniejszy cios: w późnych godzinach wieczornych w swojej rezydencji w Warszawie został aresztowany kard. Wyszyński ${ }^{26}$.

W czasie jego ,internowania” pracami Episkopatu kierował, narzucony hierarchom przez komunistów, biskup łódzki Michał Klepacz. Komuniści szantażowali Episkopat i grozili, że każdy inny kandydat na to stanowisko zostanie od razu aresztowany. Pod przewodnictwem bpa Klepacza 17 grudnia 1953 r. w Belwederze biskupi złożyli na ręce wicepremiera Józefa Cyrankiewicza upokarzające ślubowanie na wierność państwu. „Ślubuję uroczyście wierność Polskiej Rzeczypospolitej Ludowej i jej rządowi. Przyrzekam, że uczynię wszystko dla rozwoju PRL oraz umocnienia jej siły i bezpieczeństwa. Dołożę wszelkich starań, aby podległe mi duchowieństwo zgodnie ze swym obowiązkiem obywatelskim w swej działalności duszpasterskiej nawoływało wiernych do poszanowania prawa i władzy państwowej, do wzmocnienia pracy nad rozbudową gospodarki i podniesienia dobrobytu narodu. Przyrzekam, że nie podejmę niczego, co mogłoby być sprzeczne $\mathrm{z}$ interesami PRL lub godzić w bezpieczeństwo lub całość jej granic. Dbając o dobro i interes państwa, będę się starał o odwrócenie od niego wszelkich niebezpieczeństw, o których wiedziałbym, że mu zagrażają"27.

Dla człowieka utożsamiającego się z katolicyzmem, wiarą, interesami Kościoła, lektura tekstu tego ślubowania nawet dziś, po latach, musi być przykra. A przecież biskupi składali je, gdy ich arcypasterz „przebywał w miejscu odosobnienia", i to w dodatku na ręce tych, którzy go aresztowali. Co więcej, ostatnie zdanie tego ślubowania - przy odrobinie złej woli - może być interpretowane jako zapowiedź donosicielstwa, i to do-

${ }^{26}$ Dla okresu ,internowania” prymasa unikalnym źródłem pozostają wydane po raz pierwszy w Paryżu w 1982 r. i potem wielokrotnie wznawiane w kraju Zapiski więzienne kard. Wyszyńskiego. Zupełnie innego typu źródłem jest natomiast książka Kryptonim „Ptaszyńska”. Donosy na Prymasa, oprac. M. Romaniuk, Londyn 1993, zawierająca zapiski towarzyszącej Wyszyńskiemu siostry Marii Graczyk. Zob. też ks. S. Skorodecki, Jestem świadkiem, Szczecin 1999; J.Żakowski, Mroczne wnętrza. Uwięziony Prymas prywatnie w oczach wspótwięźniów i swojej siostry. Maria Leonia Graczyk, ksiądz Stanisław Skorodecki, Julia Wyszyńska, Warszawa 2000. Dość długo kwestia agentury wokół aresztowanego prymasa (siostra Maria Graczyk - „Ptaszyńska” oraz ks. Stanisław Skorodecki - „Krystyna”) pozostawała sprawą sporną, wywołującą silne emocje i kontrowersje głównie natury moralnej. Dopiero nowsze prace oparte na materiałach archiwalnych wytworzonych przez „,bezpiekę” przecięły spekulacje wokół tej sprawy. Zob. Stefan Kardynał Wyszyński Prymas Polski w dokumentach aparatu bezpieczeństwa PRL (1953-1956), oprac. B. Piec, Warszawa 2001; W.J. Wysocki, Osaczanie Prymasa. Kardynat Stefan Wyszyński jako „podopieczny” aparatu bezpieczeństwa w latach 1953-1956, Warszawa 2002. Zob. też: B. Noszczak, Polityka państwa wobec Kościoła rzymskokatolickiego w Polsce w okresie internowania prymasa Stefana Wyszyńskiego 1953-1956, Warszawa 2008.

27 „Dziennik Ustaw” 1953, nr 10, poz. 31. 
nosicielstwa dotyczącego nawet potencjalnych zagrożeń PRL. Podobne ślubowania musieli wówczas składać wszyscy księża. Natomiast ci, którzy się od tego uchylali, byli pozbawiani prawa pełnienia funkcji kościelnych. Wydawać się więc mogło, że władze państwowe zrealizowały swój cel i doprowadziły - przynajmniej w pewnym stopniu - do wasalizacji Kościoła katolickiego, ostatniej siły, która nie chciała się im do końca podporząadkować i zachowywała odrębność. Prymas miał więc do biskupów - nie wyrażony zresztą nigdy wprost - żal o to, że nie przeciwstawili się tej akcji bardziej stanowczo.

Nie ulega wątpliwości, że w dziejach PRL rozpatrywanych w praktyce na wszelkich możliwych płaszczyznach - politycznej, społecznej, ekonomicznej, kulturowej itd. - szczególnie ważną cezurą pozostaje rok 1956. Jest to także bardzo ważna data w powojennych dziejach stosunków Kościół-państwo. Jesienią, gdy na czele PZPR stanął Władysław Gomułka, w obliczu napiętej sytuacji w kraju komuniści zdecydowali się na dość liczne pojednawcze gesty pod adresem społeczności katolickiej. W pierwszej kolejności został zwolniony z „internowania” kard. Wyszyński, który od razu powrócił do swoich funkcji publicznych i duszpasterskich. Aktywnie patronował normalizacji stosunków z władzami państwowymi. Przyczyniało się do niej zwolnienie z więzień duchownych wtrąconych tam bezprawnie w „minionym okresie”. Wyrażono zgodę na działalność Klubów Inteligencji Katolickiej w Krakowie, Poznaniu, Toruniu, Warszawie i Wrocławiu. Gomułka przystał też na to, aby w Sejmie po wyborach ze stycznia 1957 r. znalazła się kilkuosobowa reprezentacja posłów katolickich, w tym trzy osoby (Stefan Kisielewski, Stanisław Stomma i Jerzy Zawieyski) ze środowiska zwróconego właśnie prawowitej redakcji „Tygodnika Powszechnego".

Jesienią 1956 r. przywrócono też nauczanie religii w szkołach, przy czym była ona przedmiotem nieobowiązkowym. Wreszcie 31 grudnia władze państwowe ogłosiły nowy dekret „o organizowaniu i obsadzaniu stanowisk kościelnych", w którym przyznawały sobie mniejsze uprawnienia w sprawach organizacyjnych Kościoła. Przystały także na podjęcie pracy przez Komisję Wspólną Rządu i Episkopatu. W porównaniu z okresem stalinowskim były to zmiany ogromne, a co więcej, w odróżnieniu od tych na wielu innych polach, akurat te okazały się stosunkowo trwałe. Niezależnie od późniejszych kryzysów w stosunkach Kościół-państwo już nigdy nie przybrały one takiego charakteru, jaki miały w pierwszej połowie lat pięćdziesiątych. Nie znaczy to oczywiście, że władze komunistyczne definitywnie zrezygnowały z akcji totalnej ateizacji i laicyzacji państwa i jego instytucji. Mogły jednak powrócić do niej dopiero po pewnym czasie, gdy opanowały ferment społeczny z połowy lat pięćdziesiątych. 
Stosunki Kościół-państwo zaczęły się ponownie pogarszać w 1958 r., kiedy to władze partyjno-państwowe stopniowo zaczęły wycofywać się $\mathrm{z}$ ustępstw poczynionych wobec Kościoła i wiernych w chwili głębokiego kryzysu (z punktu widzenia komunistów) jesienią 1956 r. Ponownie sięgnięto - choć w skali i zakresie w żadnym razie nieporównywalnych do okresu stalinowskiego - po politykę antyklerykalną. To pogorszenie relacji dwustronnych przynajmniej częściowo było konsekwencją zainicjowanej wówczas kościelno-państwowej rywalizacji o kształt i charakter Milenium. W 1966 r. mijało tysiąc lat od czasu, gdy Mieszko I przyjął chrzest. Od tego momentu zwykło się symbolicznie zaczynać udokumentowaną źródłowo historię państwa polskiego. Jednocześnie było to wydarzenie o niezwykłej doniosłości dla dziejów Kościoła w Polsce - symbolizowało początek chrześcijaństwa na ziemiach polskich. Chociaż w obu przypadkach data miała charakter umowny (zarówno formowanie państwa, jak i przyjmowanie przez jego mieszkańców chrześcijaństwa były to procesy długotrwałe i trudno stwierdzić, że dokonały się one w sposób jednostkowy i całościowy właśnie w 966 r.), to jednak - jak się okazało - stanowiła znakomite pole do konfrontacji między władzami świeckimi a duchowny$\mathrm{mi}^{28}$. Był to w istocie spór o historyczne dziedzictwo, do którego miała się odwoływać Polska u schyłku XX w.

Stopniowo władze państwowe podejmowały szereg posunięć w sposób mniej lub bardziej bezpośredni uderzających w Kościół. Zakazano więc działalności duszpasterskiej w instytucjach zamkniętych (więzienia, wojsko, szpitale, kolonie i obozy dla dzieci), odbierano Kościołowi budynki nie służące bezpośrednio celom sakralnym oraz wprowadzono wysokie podatki, znacznie uszczuplające finanse Kościoła. Systematycznie ograniczając nauczanie religii w szkole, władze ostatecznie w $1961 \mathrm{r}$. doprowadziły do jej usunięcia ze szkół, przy czym nie bez oporów godziły się na to, aby uczono jej w przykościelnych salach katechetycznych ${ }^{29}$. Równocześnie jednak władze państwowe nie wyrażały zgody na

${ }^{28}$ Problematyce Milenium nie poświęcono jeszcze całościowego opracowania monograficznego, choć ukazało się już na ten temat kilka zbiorów dokumentów oraz szereg opracowań o charakterze wstępnym czy regionalnym. Obok wspomnianego już 7 tomu dzieła Petera Rainy należy tutaj przypomnieć: Milenium czy Tysiaclecie, red. B. Noszczak, Warszawa 2006; Obchody milenijne 1966 roku w świetle dokumentów Ministerstwa Spraw Wewnętrznych, red. W. Chudzik i in., Warszawa 1998; P. Raina, ,Te Deum” Narodu Polskiego. Obchody Tysiaclecia Chrztu Polski 1966/67, Olsztyn 1991; Uroczystości milenijne 1966 roku. Sprawozdanie urzędów spraw wewnętrznych, red. W. Chudzik i in., Warszawa 1996. Por. też Zapomniana data. W trzydziesta rocznicę Milenium Chrztu Polski, red. L. Mażewski, W. Turek, Gdańsk 1996.

${ }^{29}$ Szerzej zob.: H. Konopka, Religia w szkołach Polski Ludowej. Sprawa nauczania religii w polityce państwa (1944-1961), Białystok 1997. 
budowę nowych obiektów sakralnych, nawet w takich miejscowościach, w których w ogóle nie było tego typu budowli ${ }^{30}$.

Niemniej jednak prawdziwe załamanie w stosunkach Kościół-państwo nastąpiło dopiero w połowie lat sześćdziesiątych. Złożyło się zresztą na to kilka czynników. Po pierwsze, władze komunistyczne starały się w sposób dogodny dla siebie interpretować dorobek II Soboru Watykańskiego i przeciwstawiać „postępowych” papieży Jana XXIII i Pawła VI „reakcyjnemu” kard. Wyszyńskiemu. Po drugie, ujawniła się ostra rywalizacja państwowo-kościelna o kształt polskiego Milenium. Po trzecie wreszcie, na to załamanie się stosunków wpłynął fakt wystosowania na zakończenie II Soboru Watykańskiego „Orędzia biskupów polskich do ich niemieckich braci w Chrystusowym urzędzie pasterskim", w którym w dwadzieścia lat po zakończeniu II wojny światowej znalazły się niezapomniane słowa: „udzielamy przebaczenia i prosimy o przebaczenie” 31 .

Choć polscy biskupi wystosowali wtedy listy do konferencji episkopatów 56 krajów uczestniczących w Soborze, zapraszające ich przedstawicieli do udziału w uroczystych obchodach Tysiąclecia Chrztu Polski, to tylko ten list wzbudził gwałtowne reakcje czynników partyjno-państwowych. Partyjni przywódcy, w tym także sam Gomułka, z niebywałą brutalnością atakowali polskich biskupów, przeciwko którym mobilizowano opinię publiczną pod hasłem: „nie przebaczamy, nie zapominamy". Na marginesie wypada zauważyć, że zdecydowana większość Polaków, w tym większość praktykujących katolików, nie dojrzała chyba jeszcze wtedy do pojednania $z$ Niemcami i nie zrozumiała w pełni tego głęboko chrześcijańskiego gestu.

Gdy jednak władze państwowe niezwykle agresywnie zaczęły atakować Episkopat i prymasa, któremu imputowano jakieś niecne cele polityczne, zarzucając wręcz zdradę interesów narodowych, ogromna część Polaków opowiedziała się po stronie swoich duszpasterzy. Gomułka, który był szczególnie wrażliwy na punkcie stosunków z Niemcami, uznał Orędzie za przejaw mieszania się Episkopatu do polityki zagranicznej. Odebrał to wystąpienie jako niezgodne z polską racją stanu - tak jak on ją pojmował. Reakcje władz partyjno-państwowych należy jednak postrzegać w szerszym kontekście kościelno-państwowej rywalizacji o kształt Milenium. Władze utrudniały przebieg uroczystości kościelnych początkowo

${ }^{30}$ Na temat tego typu konfliktów szerzej patrz: A. Dudek, T. Marszałkowski, Walki uliczne w PRL 1956-1989, Kraków 1999, s. 84-123. Patrz też: Tajne dokumenty Państwo-Kościół 1960-1980, Londyn 1996.

${ }^{31}$ P. Madajczyk, Na drodze do pojednania. Wokół orędzia biskupów polskich do biskupów niemieckich z 1965 roku, Warszawa 1994; S. Stępień, Sobór Watykański II i Orędzie Episkopatu Polski do biskupów niemieckich, w: Milenium czy Tysiąclecie, s. 40-51. 
środkami administracyjnymi, a później także policyjnymi. Jednocześnie ze znacznym rozmachem organizowano świeckie obchody Tysiąclecia Państwa Polskiego. Był to najgłębszy i najtrwalszy od 1956 r. konflikt między Kościołem a państwem.

Mimo zmiany na stanowisku I sekretarza KC PZPR w dramatycznych okolicznościach Grudnia $1970^{32}$ stosunki na linii Kościół-państwo - niezależnie od werbalnych deklaracji ze strony przedstawicieli władz PRL w praktyce nie zmieniły się. Ekipa Edwarda Gierka w większym stopniu starała się dla własnych celów wykorzystywać autorytet Kościoła katolickiego, ale zarazem nie wyrzekła się myśli o porozumieniu się z Watykanem poza plecami Episkopatu. Hierarchowie, dysponując silnym poparciem ze strony Stolicy Apostolskiej, zajmowali stanowczą postawę w stosunkach z władzami państwowymi, które nadal prowadziły restrykcyjną politykę w zakresie przyznawania zezwoleń na budowę kościołów. Jednak w miarę pogarszania się sytuacji społeczno-gospodarczej kraju coraz częściej skłonne były szukać poparcia ze strony hierarchii katolickiej i uwzględniać różne dezyderaty płynące z kręgów kościelnych.

Czy zatem były takie sfery życia publicznego, w których interesy Kościoła oraz sprawujących władzę komunistów były zbieżne. Wydaje się, że takim polem, na którym stosunkowo często znajdowano porozumienie, były kwestie obyczajowe. Tytułem przykładu można tutaj przywołać zapis rozmowy przeprowadzonej 7 lutego 1977 r. przez odpowiedzialnego w KC PZPR za relacje z Kościołem katolickim członka Biura Politycznego i zarazem sekretarza KC Stanisława Kanię z sekretarzem Episkopatu Polski biskupem Bronisławem Dąbrowskim. Nie po raz pierwszy i nie ostatni partyjny dygnitarz i katolicki hierarcha mówili niemal jednym głosem. Chodziło o wywołaną przez bpa Dąbrowskiego sprawę pornografii i obrażania „uczuć religijnych w filmie, teatrze, telewizji”. Kania przewrotnie zwrócił się wówczas do biskupa: „Proszę, nie zniechęcajcie się. Piszcie i piętnujcie na kazaniach, ale nie władze, tylko pisarzy, reżyserów. Z nimi i partia nie może sobie poradzić, ulegają modzie Zachodu i w kołach artystów zachodnich mają poparcie. Zdecydowanie jesteśmy przeciwni wszelkiej goliźnie, pornografii i modzie zachodniej, gdzie artysta swoją niezależność pokazuje w goliźnie i obrażaniu innych" ${ }^{33}$. Na przełomie lat pięćdziesiątych i sześćdziesiątych wspólny język na tym polu znajdowali Gomułka i kard. Wyszyński.

${ }^{32}$ Szerzej zob. J. Eisler, Grudzień 1970. Geneza, przebieg, konsekwencje, Warszawa 2012 (wyd. 2 popr.i uzup.).

${ }^{33}$ Sprawozdanie z rozmowy w Sulejówku z panem Stanisławem Kanią, sekretarzem KC PZPR, 7 II 1977 r., w: P. Raina, Rozmowy z władzami PRL. Arcybiskup Dabrowski w stużbie Kościoła i Narodu, t. 1: 1970-1981, Warszawa 1995, s. 301-303. 
Generalnie jednak tych punktów stycznych było bardzo mało. Jak się wydaje, w latach sześćdziesiątych i siedemdziesiątych szczególny niepokój prymasa i części biskupów wywoływała kwestia nacjonalizacji ideologii komunistycznej, co - zdaniem niektórych duchownych - ze względu na znaczną atrakcyjność haseł narodowych mogło przyciągać do obozu rządzącego niemałą część katolików, a tym samym na dłuższą metę prowadzić do dalszego umocnienia się władzy komunistycznej w Polsce. Próbując walczyć z tą tendencją, w 1973 r. Episkopat ostro sprzeciwiał się sejmowej uchwale „o socjalistycznym wychowaniu młodzieży”. Prymas podkreślał, że wychowanie młodego pokolenia w Polsce musi być narodowe, a nie partyjne, gdyż partie się zmieniają, a naród trwa wiecznie. Wypada też przypomnieć, że trzy lata później w wyniku protestów Episkopatu władze zrezygnowały z konstytucyjnego zapisu uzależniającego przysługiwanie praw obywatelskich od „należnego” wypełniania obowiązków obywatelskich. Sejm przyjął poprawki do Konstytucji przy jednym głosie wstrzymującym się przewodniczącego katolickiego Koła „Znak” S. Stommy ${ }^{34}$.

Jak już wspomniano, pewien przełom we wzajemnych relacjach przyniósł dopiero wybór krakowskiego metropolity kard. Karola Wojtyły na Stolicę Piotrową. Dla milionów Polaków była to chwila niezwykła i prawdziwie historyczna. Dla władz państwa prowadzącego określoną politykę wyznaniową papież - będący jego obywatelem - stanowił nie lada problem. Formalnie należało okazywać radość z faktu, że Ojcem Świętym został Polak, faktycznie jednak było to komunistom nie na rękę. Na własny użytek pocieszali się gorzko, że „ostatecznie lepszy Wojtyła jako Papież tam niż jako Prymas tu" ${ }^{35}$. Wszelako nie mogli przeciwstawić się woli papieża pragnącego odwiedzić Polskę, skoro była ona jego ojczyzną. W trakcie spotkań w czerwcu 1979 r. ze „swoim papieżem” społeczeństwo polskie po raz pierwszy od lat poczuło swoją siłę; ludzie mogli zobaczyć, jak wielu ich jest i jaką stanowią siłę. Andrzej Paczkowski określił to kiedyś nader obrazowo: „Polacy, klękając przed papieżem, jednocześnie wstawali z kolan". Z dzisiejszej perspektywy nie ulega zaś wątpliwości, że Ojciec Święty „przebudził” rodaków. W rok po jego pierwszej pielgrzymce do kraju przez Polskę przetoczyła się największa w jej dziejach fala strajków, w wyniku której na scenie politycznej pojawił się Niezależny Samorządny Związek Zawodowy „Solidarność” - pierwsza masowa, legalna organizacja niezależna od władzy państwowej w całym bloku radzieckim.

Wydaje się jednak, że stosunki Kościół-państwo - co może zakrawać na pewien paradoks - uległy znaczącej zmianie dopiero po wprowadzeniu

\footnotetext{
${ }^{34}$ S. Stomma, Pościg za nadzieja, Paryż 1991, s. 160-163.

${ }^{35}$ K. Kąkol, Spowiedź „pogromcy” Kościoła, Olsztyn 1994, s. 90.
} 
stanu wojennego. Zarówno nowy prymas, arcybiskup Józef Glemp, jak i za jego przyzwoleniem inni reprezentanci Episkopatu wielokrotnie kontaktowali się z przedstawicielami ówczesnych władz. Prymas, który jednak nie miał charyzmy ani tym bardziej autorytetu wielkiego poprzednika, od pierwszych chwil za sprawę najważniejszą uznał działanie na rzecz utrzymania spokoju w kraju i w związku z tym apelował o „zaniechanie gwałtów, o zażegnanie bratobójczych walk”. Taka powściągliwa (zdaniem niemałej części członków i sympatyków „Solidarności” zbyt umiarkowana) postawa arcybiskupa ściągała czasem na niego głosy krytyki ze strony niektórych internowanych lub funkcjonujących w podziemiu działaczy związkowych. Niemniej jednak należy tutaj wyraźnie podkreślić, że w stanie wojennym Kościół odgrywał zupełnie wyjątkową rolę. Był jedyną organizacją cieszącą się autentycznym autorytetem i szacunkiem społecznym, na której otwarte zaatakowanie władze się nie zdobyły.

Poza tym to właśnie Kościół organizował i prowadził akcje pomocy charytatywnej dla internowanych i aresztowanych działaczy solidarnościowej opozycji oraz ich rodzin. W 1982 r. instytucje Kościoła katolickiego stały się też azylem dla bardzo wielu ludzi ze świata kultury, sztuki i nauki, w przeszłości nierzadko bardzo odległych od katolicyzmu, a nieraz i wrogich religii. W tym miejscu warto wspomnieć o organizowanych od 1975 r., początkowo z inicjatywy ks. Wiesława Niewęgłowskiego oraz ks. Tadeusza Uszyńskiego, Tygodniach Kultury Chrześcijańskiej, które właśnie w okresie stanu wojennego zyskały szczególną rangę, przyczyniając się do unikalnego w polskiej historii zbliżenia środowisk religijnych i artystycznych; inna rzecz, że już w drugiej połowie lat osiemdziesiątych ich drogi zaczęły się rozchodzić.

Tymczasem - mimo że część duchownych nie ukrywała swoich sympatii dla podziemnej „Solidarności” - w latach osiemdziesiątych rządzący starali się traktować Kościół nieco inaczej niż wcześniej. Nigdy przedtem w powojennej Polsce nie budowano tylu obiektów sakralnych co właśnie wtedy. Jednocześnie stosunkowo często dochodziło wówczas do spotkań przedstawicieli Episkopatu i władz państwowych, co - jak się potem okazało - miało tę dobrą stronę, że w latach 1988-1989 niektórzy duchowni mogli być pomocni przy inaugurowaniu rozmów Okrągłego Stołu jako pośrednicy między „Solidarnością” a przedstawicielami władzy państwowej. Dla strony solidarnościowej pełnili swoistą rolę gwaranta, że druga strona będzie postępowała zgodnie z zasadami; dla przedstawicieli władzy zaś rolę czynnika powściągającego ewentualne nadmierne żądania ludzi „Solidarności". Nie sposób przy tym sobie wyobrazić, by biskupi mogli odgrywać podobną rolę mediatora choćby dziesięć lat wcześniej. Chociaż przedstawiciele Kościoła zachowywali - jak się wydaje - neutralność, to przecież jest 
oczywiste, że w nieporównanie większym stopniu utożsamiali się z interesami i racjami „Solidarności” niż władzy komunistycznej.

W niniejszym szkicu nie ma miejsca, aby porównywać pozycję i sytuację Kościoła katolickiego w Polsce do tej w innych państwach rządzonych przez komunistów. Wystarczy jednak przypomnieć, że mimo tego wszystkiego, co powyżej napisałem, była ona nieporównanie lepsza niż w którymkolwiek z nich. Zresztą na ten temat pojawiło się już trochę opracowann ${ }^{36}$. Zapewne jeszcze trudniej byłoby porównywać stopień dechrystianizacji w poszczególnych z tych państw. Należałoby przy tym wziąć pod uwagę wiele czynników, przy czym nie najmniej ważny byłby stopień zeświecczenia tych społeczeństw oraz państw (kwestia szczególnie może ważna w wypadku Czechosłowacji) przed okresem przejęcia w nich władzy przez komunistów.

Zresztą gdy mówimy o dechrystianizacji współczesnej Europy, bardzo starannie trzeba oddzielać procesy laicyzacyjne zachodzące (w różnym zresztą tempie i zakresie) w poszczególnych społeczeństwach od procesów zeświecczania instytucji oraz mechanizmów funkcjonowania konkretnych państw. W tym miejscu chciałbym zwrócić uwagę na to, że w państwach o długiej tradycji katolickiej - zarówno takich jak Francja, Hiszpania czy Włochy, które nie przechodziły okresu rządów komunistycznych, jak i takich, które jak Chorwacja, Polska czy Słowacja przez dziesięciolecia pozostawały pod władzą komunistów - na mocy obowiązujących przepisów dyplomatyczni przedstawiciele Stolicy Apostolskiej w randze nuncjuszy są zwyczajowo dziekanami korpusu dyplomatycznego, chociaż zwykle (tak było na przykład w PRL) ta zaszczytna funkcja przypada temu ambasadorowi, który najdłużej pełni misję w danym kraju.

Na pewno dyskutując o stopniu zeświecczenia współczesnej Europy i Polski w tejże Europie, należy zachować dużą ostrożność i powściągliwość w formułowaniu generalnych wniosków. Faktycznie stosunkowo często mamy do czynienia z konsumpcjonizmem i hedonistycznym stosunkiem do życia znacznej części społeczeństwa. Nie można także zamykać oczu na niestety stale obecny brak poszanowania dla ludzkiego

${ }^{36}$ Tytułem przykładu zob.: B. Cywiński, Ogniem próbowane. Z dziejów najnowszych Kościoła katolickiego w Europie Środkowowschodniej, t. 2: „...i was prześladować będa”, Lublin-Rzym 1990; A. Grajewski, Kompleks Judasza. Kościół zraniony. Chrześcijanie w Europie Środkowo-Wschodniej między oporem a kolaboracją, Poznań 1999; Represje wobec duchowieństwa kościołów chrześcijańskich $w$ okresie stalinowskim $w$ krajach byłego bloku wschodniego, red. J. Myszor, A. Dziurok, Katowice 2004. 
życia, a ilość zła i niesprawiedliwości na świecie wcale nie wydaje się mniejsza niż kiedyś. Zarazem jednak można by na przykład długo zastanawiać się nad tym, czy ludzie, którzy - po terrorystycznym ataku lotniczym 11 września 2001 r. na World Trade Center w Nowym Jorku - przed siedzibami amerykańskich ambasad w różnych krajach (nie tylko w Polsce) spontanicznie składali kwiaty i zapalali świeczki, znicze, lampki, robili to w geście solidarności z ofiarami i współczucia dla ich rodzin, czy w proteście przeciwko niewyobrażalnej do tego momentu tego typu zbrodni, czy z powodu własnych pobudek religijnych. A może wszystkie te czynniki i jeszcze wiele innych łączyło się tutaj w pewną nierozerwalną całość?

Gdy dyskutujemy o odejściu od wiary i od instytucjonalnego Kościoła na Starym Kontynencie milionów ludzi, warto jednak także pamiętać o tym, że w grudniu 2004 r. - po gigantycznym tsunami na Dalekim Wschodzie, w którym zginęło około trzystu tysięcy ludzi, w tym wielu europejskich turystów spędzających tam Święta Bożego Narodzenia ${ }^{37}$, w kościołach w wielu krajach odbyły się uroczyste nabożeństwa żałobne, w których uczestniczyły najważniejsze osobistości: królowie, prezydenci, szefowie rządów, ministrowie itd. Nie inaczej było w Holandii po strąceniu latem 2014 r. nad wschodnią Ukrainą samolotu pasażerskiego Malezyjskich Linii Lotniczych i w Niemczech po katastrofie w Alpach w marcu 2015 r. samolotu Germanwings, a przecież Holandię i Niemcy zalicza się powszechnie do tych państw, w których procesy zeświecczenia czy wręcz dechrystianizacji zaszły najdalej.

Jeżeli zatem współczesna Polska bywa niekiedy na Zachodzie przedstawiana jako jeden wielki „katolicki skansen” Starego Kontynentu, to jest to przede wszystkim kwestia punktu odniesienia, przy czym są nim w tym wypadku bogate, zeświecczone, zlaicyzowane demokratyczne i liberalne państwa Europy Zachodniej, na dodatek często o tradycji protestanckiej. Zresztą niezależnie od tego, czy i w jakim stopniu zasadne jest nazywanie Polski „katolickim skansenem” Europy, należy stwierdzić, iż jest wiele przyczyn takiego stanu rzeczy. Obok pospolitej na Zachodzie niewiedzy, karmiącej się dawno już zdezaktualizowanymi stereotypami, oraz bezdyskusyjnego ekonomicznego zacofania Polski w porównaniu do najbogatszych i najwyżej rozwiniętych państw Zachodu, dopatrywałbym się w tym konsekwencji decyzji kard. Wyszyńskiego i Episkopatu Polski z lat sześćdziesiątych, aby dorobku Soboru Watykańskiego II nie wprowadzać w Polsce zbyt szybko i nie w nazbyt szerokim zakresie. Rozumowanie to - wbrew temu, co można czasem usłyszeć - było efek-

${ }^{37}$ Szwedów więcej jednego dnia zginęło ostatni raz 8 lipca 1709 r. w czasie bitwy pod Połtawą. 
tem nie tyle silnego konserwatyzmu prymasa i polskich biskupów, ile sytuacji, w jakiej znajdował się Kościół katolicki w niedemokratycznej i niesuwerennej Polsce.

Mając naprzeciw siebie scentralizowaną, niemal monolityczną i monopolistyczną władzę z jednoosobowym kierownictwem Gomułki, Wyszyński nie bardzo mógł sobie pozwolić na eksperymentowanie i choćby częściową decentralizację własnej władzy. Wygląda na to, że z podobnych powodów obawiał się także wzmocnienia roli laikatu, w czym dostrzegał groźbę osłabienia spoistości Kościoła. Wszystko to razem doprowadziło jednak z czasem do stanu pewnej hibernacji, swoistego (przynajmniej częściowego) zamrożenia w Polsce katolicyzmu w kształcie przedsoborowym oraz utrwalenia niezwykle silnego nurtu katolicyzmu ludowego, maryjnego. Chcę być przy tym dobrze zrozumiany. Nie uważam tego nurtu w katolicyzmie za coś niewłaściwego czy tym bardziej gorszego. Co więcej, w realiach okresu poprzedzającego pontyfikat papieża Jana Pawła II taki właśnie typ religijności być może uchronił Kościół i społeczeństwo w Polsce przed zeświecczeniem, a może i dechrystianizacją...

\section{People's Republic of Poland - a Sketch for Reflections about the Laicization of the State}

The intention of this text was to ponder on, and attempt to resolve questions whether and to what degree did the laicization policy and atheization campaign conducted by successive political teams in Poland after the Second World War contribute to and accelerate the Dechristianization of Polish society, a process discernible also in other Europe states. What factors (political, social, economic, cultural, etc.) favoured such processes and what sort delayed or outright hampered them? What was the role performed by the Polish Episcopate and its long-term head - Cardinal Stefan Wyszyński, the Primate of Poland, who intentionally did not hasten the transference onto Polish ground of the accomplishments of the Second Vatican Council? Another significant issue involved the character and intensity of the processes in question. Did they contribute to the modernization of the state and society or, on the contrary, did they conserve their former structure?

The author paid considerable attention to the mutual Church-state relations in communist-ruled Poland. It cannot be said that at any time during this period did they resemble those between partners, albeit they indubitably evolved. Such transformations were the consequence of both the internal situation and changes transpiring on the international arena. The foremost premise of all vicissitudes affecting the relations between the Church and the state in post-war Poland (the election of Cardinal Karol Wojtyła as Pope, 1978) possessed both domestic and international dimensions. 